\title{
Analisis Peraturan Tentang Praktik Monopoli Dan Persaingan Usaha Tidak Sehat Terhadap Perubahan Jenis Produksi Perusahaan Dalam Masa Pandemi Covid19 Di Indonesia
}

\author{
Arief Tharifi \\ Fakultas Hukum Universitas Indonesia \\ Email: arieftharifi97@gmail.com
}

\begin{abstract}
Abstrak
Indonesia adalah sebuah Negara yang berlandaskan hukum, oleh sebab itu Indonesia mengatur segala kegiatan yang dilakukan oleh masyrakatnya dengan bedasarkan hukum. Awal tahun 2020 menjadi sebuah peristiwa besar yang sangat berpengaruh diseluruh dunia yaitu terjadinya pandemic sebuah virus yang bernama Covid19 dimana pandemic ini mengganggu seala aktivitas masyarakat dunia disebabkan virus yang menyebar pada sesame manusia sehingga World Health Organization (WHO) mengeluaran himbauan untuk seluruh masyarakat tetap berada dirumah, hal ini menyebabkan kegiatan ekonomi pun terganggu. Sejak pertumbuhan ekonomi menurun pemerintah mengambil beberapa kebijakan dengan memberi beberapa kemudahan pada pelaku usaha di Indonesia, salah satunya dengan memberikan kemudahan pajak bea masuk dalam mengimpor barang guna produksi alat kesehatan yang semakin langa dan sangat dibutuhkan dalam mengadapi pandemic tersebut. Hal ini menyebabkan banyaknya perusahaan yang berlomba-lomba untuk mengubah jenis produksinya menjadi produksi alat kesehatan. Kejadian ini dapat membuat muncul persaingan usaha tidak sehat yang dilakukan oleh pelaku usaha besar yang dapat mengganggu pelaku usaha yang sebelumnya sudah memiliki izin untuk produksi alat kesehatan. Permasalahan yang penulis angkat adalah bagaimana aturan hukum di Indonesia menjawab masalah perubahan jenis produksi tersebut. Hasil penelitian ini memperlihatkan bahwa perubahan dan kebijakan pemerintah untuk merubah jenis produksi perusahaan itu dibenarkan secara hokum disebabkan selama adanya keadaan yang berpengaruh pada orang banyak dan ditunjuk oleh undang undang, maka terjadinya praktik monopoli sekalipun dapat dibenarkan. Saran yang dapat penulis berikan seharusnya pemerintah lebih memperketat pengawasan terhadap pelaku usaha yang merubah produksinya yang disebabkan oleh pandemic seperti ini.
\end{abstract}

Kata Kunci: Covid19, Persaingan Usaha, Produksi, Kebijakan

\begin{abstract}
Indonesia is a law-based country, therefore Indonesia governs all activities undertaken by its community based on the law. Early in 2020 became a major event that is very influential around the world, namely the occurrence of pandemic a virus named COVID19 where this pandemic interfere with the activity of world society because of viruses that spread in human sesame so that the World Health Organization (WHO) to eliminate the appeal for the whole community remains at home, this causes economic activities are disrupted. Since the economic growth declined the government has taken several policies by giving some convenience to business actors in Indonesia, one of them by providing the convenience of tax import duty in importing goods to the production of health equipment is increasingly langa and much needed in the pandemic. This led to the sheer number of companies that competed to change the production type into medical devices. This incident can make emerging unfair business competition conducted by large business actors who can interfere with the business people who previously have permission to the production of medical equipment. The problem that the author adopted is how the rule of law in Indonesia answered the problem of changing the type of production. The results of this research show that the change and policy of government to change the production type of the company is justified in a legal way due to the circumstances that affect the crowd and appointed by law, hence the practice of monopoly even
\end{abstract}


justified. Suggestions that can be given by the Government should strengthen supervision of business people who change the production caused by pandemic like this.

Keywords: COVID19, business competition, production, policy

\section{PENDAHULUAN}

\section{A. Latar Belakang}

Indonesia adalah Negara yang memiliki berbagai kekayaan alam dan keberagaman budaya yang terhampar dari sabang sampai merauke, factor factor ini menjadi salah satu alasan bahwa Indonesia menjadi lokasi yang cocok dalam hal mengembangkan bisnis dan investasi serta menjadi destinasi pariwisata bagi masyarakat Internasional, sebagai sebuah Negara berkembang Indonesia membutuhkan pajak sebagai pemasukan Negara baik dari masyrakatnya, bea masuk barang impor, serta visa masyarakat luar negeri yang ingin masuk ke wilayah Indonesia yang menyebabkan Indonesia membuka peluang luas agar pebisnis atau turis luar negeri berlalulalang di dalam negeri.

Tahun 2020 menjadi tahun yang cukup berat untuk Dunia khususnya Indonesia, sebuah wabah virus yang bernama Covid Virus Disease (Covid19) yang merebak ke seluruh penjuru dunia membuat kegiatan masyarakat dunia terganggu hingga anjloknya pertumbuhan ekonomi, Virus corona atau Covid-19 pertama kali ditemukan di Wuhan, China pada akhir 2019 lalu. Penyebaran virus yang belum ditemukan penawarnya itu hingga kini tak terkendali. Sudah 200 lebih negara di dunia melaporkan adanya kasus terpapar virus corona.

Di Indonesia kasus ini pertama kali ditemukan pada dua warga Depok, Jawa Barat awal Maret lalu. Data hingga Sabtu, 28 Maret 2020 jumlah warga yang dinyatakan positif terkena virus corona mencapai 1.155 dan 102 di antaranya meninggal dunia.Cepatnya penyebaran virus ini di Indonesia menurut Juru Bicara pemerintah untuk penanganan COVID19, Achmad Yurianto karena banyak warga yang tak mengikuti imbauan untuk tetap di rumah.

Pemerintah Indonesia melalui Presiden Jokowidodo mengeluarkan kebijakan Pembatasan Sosial Berskala Besar (PSBB) sebagai salah satu langkah untuk pencegahan penularan virus Covid19, kebijakan ini mengharuskan seluruh massyarakat Indonesia harus berkegiatan dan bekerja dari rumah kecuali yang bekerja pada bidang bidang vital seperti kesehatan, keamanan, pertahanan, pangan, dan energy. Dengan pembatasan kegiatan seperti ini tentu saja akan sangat berdampak dengan lemahnya ekonomi disebabkan banyak beberapa sector usaha yang diharuskan untuk vakum atau bahkan tutup. Masalah ini mulai bertambah dengan adanya syarat dan perintah dari WHO (World Health Organization) sebagai organisasi kesehatan dunia untuk menerapkan protocol kesehatan dengan menggunakan masker oleh setiap orang diseluruh dunia agar menghidari penularan virus korona, hal ini menyebabkan permintaan untuk kebutuhan masker menjadi meningkat drastis, hal ini dimanfaatkan oleh pelaku usaha yang tidak bertanggung jawab untuk menimbun stok masker yang mereka punya dengan harapan masker menjadi langka dan dapat dijual kembali dengan harga yang sangat tinggi sehingga mereka bisa mendapatkan keuntungan yang sangat besar.

Dengan adanya fenomena ini, pemerintah sebagai otoritas Negara mengambil beberapa langkah dengan mengeluarkan beberapa kebijakan dan himbauan, salah satunya adalah dengan mendorong masyarakat untuk membuat dan memproduksi masker secara individu dan mengurangi penggunaan masker untuk keperluan medis yaitu masker N95 dan juga masker bedah, selain itu pemerintah juga memberikan keringanan-keringanan serta mendorong perusahaan-perusahaan yang pada awalnya tidak memproduksi masker untuk dapat merubah jenis produksinya menjadi masker medis yang diperlukan untuk menghadapi pandemi virus tersebut.

Perusahaan-perusahaan mengubah rantai produksi mereka karena berbagai alasan. Di AS, pemerintah mereka menerapkan UU Produksi Pertahanan yang memerintahkan beberapa perusahaan seperti GM untuk membuat ventilator. Namun mayoritas 
perusahaan yang mengubah produksi melakukannya dengan suka rela, dengan tujuan menjaga produksi dan pendapatan ketika permintaan yang biasa menghilang. Ada pula nilai lebih di baliknya, mereka bisa dibilang turut membantu masyarakat secara lebih luas, yang artinya reputasi mereka di mata publik meningkat. Membuat produk kebersihan dan perlindungan yang sederhana biasanya lebih mudah, jika perusahaan mau mengadaptasi peralatan dan melakukan riset dasar, maka membuat masker dan pembersih tangan bisa dilakukan dalam hitungan hari. Seperti Royal Mint yang berada di Wales, Inggris, yang mulai memproduksi pelindung wajah plastik untuk pekerja kesehatan pada akhir Maret, selain tetap memproduksi koin dan produk investasi logam. Dalam waktu singkat setelah mereka 'banting setir', Royal Mint telah memproduksi 30.000 pelindung wajah. Fenomena ini terjadi hampir diseluruh Negara yang ada didunia, bukan hanya mengalihkan produksi menjadi masker tetapi mereka berlomba- lomba untuk mengubah produksi menjadi alat-alat kesehatan lain yang sangat dibutuhkan pada saat pademi virus seperti saat ini.

Indonesia adalah negara kepulauan terluas di dunia dengan luas wilayah 1.910.931,32 m2 dan terdiri dari 17.504 pulau (BPS, 2015). Hasil sensus penduduk tahun 2010 menyebutkan bahwa jumlah penduduk Indonesia mencapai 237.641.326 jiwa dan diprediksi pada tahun 2015 mencapai sekitar 255.461.700 jiwa. Untuk memenuhi salah satu kebutuhan akan kesehatan yaitu sarana pelayanan kesehatan. Sebagai pendukung pelayanan kesehatan, ketersediaan sarana kefarmasian dan alat kesehatan yang terdiri atas sarana produksi dan distribusi jumlahnya masih belum merata untuk seluruh wilayah Indonesia. Jumlah sarana terbanyak berada di pulau Sumatera dan Jawa. Sarana produksi di bidang kefarmasian dan alat kesehatan jumlahnya sebesar 2.817 sarana. Sedangkan untuk sarana distribusi jumlahnya sebesar 35.556 saranaHasil pemetaan sarana produksi alat kesehatan tahun 2013 menunjukkan bahwa hanya ada 192 sarana yang tersebar di 11 propinsi (Indonesia, 2016). Data di atas memperlihatkan bahwa dengan luasnya wilayah Indonesia dan semakin meningkatnya jumlah penduduk menyebabkan kebutuhan akan kesehatan juga ikut meningkat, mulai dari kebutuhan sarana pelayanan kesehatan hingga sumber daya, tenaga kesehatan hingga perbekalan kesehatan. Salah satu kebutuhan perbekalan kesehatan yang kebutuhannya meningkat adalah alat kesehatan. Alat kesehatan merupakan salah satu bagian penting dalam pelayanan kesehatan yang digunakan untuk membantu dalam pencegahan, penegakkan diagnosa, pengobatan maupun pemulihan penyakit. Akan tetapi, hingga saat ini, alat kesehatan yang beredar di Indonesia masih lebih banyak dikuasai oleh produk impor yang persentasenya mencapai lebih dari $90 \%$.

Kebutuhan alat kesehatan juga semakin meningkat sejak hadirnya program Jaminan Kesehatan Nasional (JKN) dimana prinsip $\mathrm{JKN}$ adalah memberikan layanan yang bersifat komprehensif, artinya pengobatan untuk semua jenis penyakit dijamin, baik pengobatan yang murah maupun mahal, tetapi tetap costeffective (Thabrany, 2014). Dari sisi nilainya, alat kesehatan memiliki nilai yang cukup besar. Nilai pasar alat kesehatan Indonesia pada tahun 2013 mencapai US\$672,8 juta dan dengan pertumbuhan sekitar $12 \%$ per tahun diperkirakan pada tahun 2018 nilainya akan mencapai US $\$ 1.221,9$ juta (BMI, 2016). Terus meningkatnya kebutuhan dan besarnya pasar alat kesehatan serta program Pemerintah dalam mewujudkan kemandirian ekonomi dengan menggerakkan sektor-sektor strategis ekonomi domestik, maka Pemerintah menetapkan industri alat kesehatan sebagai salah satu industri prioritas untuk dikembangkan.

Indonesia adalah Negara hukum dimana segala sesuatu kegiatan diatas territorial Indonesia harus dilandaskan dan dijalankan berdasarkan aturan hukum yang berlaku, Dunia usaha merupakan suatu dunia yang boleh dikatakan tidak dapat berdiri sendiri. Banyak aspek dari berbagai macam dunia lainnya yang turut terlibat baik langsung maupun tidak langsung dengan dunia usaha ini. Keterkaitan tersebut kadang kala tidak memberikan prioritas atas dunia usaha, yang pada akhirnya membuat dunia usaha harus tunduk dan mengikuti rambu-rambu yang ada 
dan sering kali bahkan mengutamakan dunia usaha sehingga mengabaikan aturan-aturan yang ada.

Hukum sangat dibutuhkan untuk mengatur kehidupan bermasyarakat di dalam segala aspeknya, baik itu kehidupan sosial, politik, budaya serta peranannya dalam pembangunan ekonomi. Dalam kegiatan ekonomi inilah justru hukum sangat diperlukan, karena sumber-sumber ekonomi yang terbatas disatu pihak dan tidak terbatasnya permintaan atau kebutuhan akan sumber ekonomi dilain pihak, agar dapat mencegah timbulnya konflik antara sesama warga dalam memperebutkan sumber-sumber ekonomi tersebut. Jelas bahwa hukum mempunyai peranan penting dalam pembangunan ekonomi untuk mewujudkan kesejahteraan sosial. Pada prinsipnya, setiap orang berhak menjual atau membeli barang atau jasa "apa", "dengan siapa", "berapa banyak", serta "bagaimana cara" produksi, inilah yang disebut dengan ekonomi pasar. Sejalan dengan itu, perilaku dan struktur pasar terkadang tidak dapat diprediksi sehingga tidak jarang pelaku usaha melakukan kecurangan, pembatasan yang menyebabkan sebagian atau beberapa pihak mengalami kerugian. Menurut Mustafa Kamal Rokan, secara makro, saat ini kecenderungan banyak negara menganut pasar bebas, di mana pelaku usaha "secara bebas" dapat memenuhi kebutuhan konsumen dengan memberikan produk yang beragam sekaligus efisien.

Kebebasan pasar dalam sistem ini tidak jarang membuat pelaku melakukan perbuatan (behavior) yang membentuk struktur pasar (market structure) yang bersifat monopolistik atau oligopolistik. Pembentukan struktur pasar (market structure) yang bersifat monopolistik atau oligopolistik merupakan perwujudan dari kondisi persaingan usaha yang tidak sehat. Monopoli adalah komponen utama yang akan membuat kekayaan terkonsentrasi ditangan segelintir kelompok sehingga dapat menciptakan kesenjangan sosial dan ekonomi. Kepemilikan dan penguasaan aset kekayaan ditangan individu mengenai sesuatu yang diperbolehkan, namun demikian ketika kebebasan tersebut dimanfaatkan untuk menciptakan praktik-praktik monopolistik yang merugikan di mana tugas kewajiban negara untuk melakukan intervensi dan koreksi. Pembangunan ekonomi yang seiring dengan timbulnya kecenderungan globalisasi perekonomian, maka bersamaan itu semakin banyak pula tantangan yang dihadapi dalam dunia usaha, antara lain persaingan usaha atau perdagangan yang menjurus kepada persaingan produk/komoditi dan tarif, sebab perekonomian sekarang merupakan perdagangan globalisasi antarnegara.

Dalam kondisi normal setiap kegiatan usaha akan diatur sedemikan rupa untuk mencegah adanya praktik monopoli dan persaingan usaha tidak sehat agar tetap menjaga keseimbangan kesempatan diantara para pelaku usaha demi tumbuh dan berkembangnya perekonomian bangsa, dalam kondisi normal pemerintah dapat mengawasi setiap tindak tanduk pelaku usaha agar tetap dalam koridor yang benar sesuai dengan Undang -Undang Nomor 5 Tahun 1999 tentang Larangan Praktik Monopoli dan Persaingan Usaha Tidak Sehat, tetapi bagaimana pengaturan pelaku usaha ini dalam kondisi pandemic virus seperti tahun 2020 ini, yang membuat beberapa perusahaan bahkan perusahaan-perusahaan besar berlomba-lomba untuk merubah produksi mereka dan memasarkan produk mereka dengan alat kesehatan, bagaimana posisi perusahaan yang pada awalnya sudah memproduksi alat kesehatan, tentunya mereka akan terganggu dengan kebijakan pemerintah untuk mendorong dan memberikan insentif insentif kepada perusahaan yang sebelumnya bukan produsen alat kesehatan sekarang menjadi produsen alat kesehatan, hal ini tentunya dapat mengancam eksistensi perusahaan yang murni menjadi produsen alat kesehatan serta rentan terjadinya Praktik monopoli dan persaingan usaha tidak sehat.

Berdasarkan latar belakang tersebut diatas maka penulis tertarik untuk meneliti dan menuangkan kedalam tulisan yang berjudul "Analisis Peraturan Tentang Praktik Monopoli dan Persaingan Usaha Tidak Sehat Terhadap Perubahan Jenis Produksi Perusahaan Dalam Masa Pandemi COVID19 di Indonesia" 


\section{B. Rumusan Masalah}

Dengan demikian berdasarkan uraian latar belakang dan judul diatas maka untuk itu penulis merumuskan permasalahan sebagai berikut:

1. Bagaimanakah peraturan perundangundangan mengenai praktik monopoli dan persaingan usaha tidak sehat menghadapi perubahan jenis produksi perusahaan dalam masa pandemi covid19 di Indonesia?

\section{PEMBAHASAN}

Hukum Indonesia dalam bidang persaingan usaha tidak sehat telah mengatur sedemikan rupa dalam mengontrol tindakantindakan para pelaku usaha agar tidak melewati batas batas yang telah disiratkan oleh undang-undang, persaingan usaha diatur dalam Undang Undang Nomor 5 Tahun 1999 tentang Larangan Praktik Monopoli dan Persaingan Usaha tidak sehat dengan tujuan yang dibuat dengan beberapa pertimbangan diantaranya;

a) bahwa pembangunan bidang ekonomi harus diarahkan kepada terwujudnya kesejahteraan rakyat berdasarkan Pancasila dan Undang-Undang Dasar 1945;

b) bahwa demokrasi dalam bidang ekonomi menghendaki adanya kesempatan yang sama bagi setiap warga negara untuk berpartisipasi di dalam proses produksi dan pemasaran barang dan atau jasa, dalam iklim usaha yang sehat, efektif, dan efisien sehingga dapat mendorong pertumbuhan ekonomi dan bekerjanya ekonomi pasar yang wajar;

c) bahwa setiap orang yang berusaha di Indonesia harus berada dalam situasi persaingan yang sehat dan wajar, sehingga tidak menimbulkan adanya pemusatan kekuatan ekonomi pada pelaku usaha tertentu, dengan tidak terlepas dari kesepakatan yang telah dilaksanakan oleh negara Republik Indonesia terhadap perjanjian-perjanjian internasional;

Sejak terjadinya pandemic virus Covid 19 di Indonesia terdapat beberapa kebijakan yang dikeluarkan pemerintah untuk memberikan insentif dan keringanan bagi para pelaku usaha besar, menengah ataupun kecil untuk dapat memproduksi, mengimpor dan memasarkan barang berupa alat kesehatan di wilayah Indonesia salah satunya telah dikeluarkan oleh Menteri Keuangan dengan Peraturan menteri keuangan Nomor 34/PMK.04/2020 tentang Pemberian Fasilitas Kepabeanan dan/atau Cukai Serta Perpajakan Atas Impor Barang untuk Keperluan Penanganan Pandemi Coronavirus Disease 2019 (COVID-19).

Menurut PMK tersebut, ada pembebasan bea masuk, Pajak Pertambahan Nilai (PPN) atas barang mewah, dan Pajak Penghasilan (PPh) Pasal 22 untuk berbagai produk kesehatan seperti ventilator, alat perlindungan diri (APD), masker, cairan pembersih tangan (hand sanitiser), sarung tangan, disinfektan, alat tes kilat (rapid testing kit), alat tes PCR, obat, dan vitamin. Dalam peraturan ini terdapat beberapa aturan yang memberikan kemudahan dalam mengimpor alat-alat kesehatan diantaranya terdapat dalam pasal 2 yang berbunyi:

Atas impor barang untuk keperluan penanganan pandemi corona virus disease 19 (Covid19) diberikan fasilitas kepabeanan dan/atau cukai serta perpajakan berupa:

a. pembebasan biaya masuk dan/atau cukai

b. tidak dipungut pajak pertambahan nilai atau pajak pertambahan nilai dan pajak penjualan atas barang mewah; dan

c. dibebaskan dari pemungutan pajak penghasilan pasal 22

Dengan dasar pasal tersebut diatas banyak perusahaan yang berlomba lomba untuk memproduksi alat kesehatan dan mengimpor baik barang mentah dan barang jadi untuk dapat memproduksi dan memasarkan produk alat kesehatan di Indonesia. Dengan terjadinya hal tersebut maka timbul pertanyaan, bagaimana hak hak yang dimiliki oleh perusahaan yang sebelumya memiliki jenis produksi yang sebelumnya sudah menjadi produsen alat kesehatan, karna banyak industry besar yang turut merubah produksinya kepada alat kesehatan disebabkan peluang yang ada.

Terdapat beberapa pasal dalam UU nomor 5 tahun 1999 yang diterapkan untuk mencegah akan adanya persaingan usaha yang tidak sehat 
dikarenakan praktik tersebut diatas diantaranya:

\section{Pasal 13}

(1) Pelaku usaha dilarang membuat perjanjian dengan pelaku usaha lain yang bertujuan untuk secara bersama-sama menguasai pembelian atau penerimaan pasokan agar dapat mengendalikan harga atas barang dan atau jasa dalam pasar bersangkutan, yang dapat mengakibatkan terjadinya praktek monopoli dan atau persaingan usaha tidak sehat.

(2) Pelaku usaha patut diduga atau dianggap secara bersama-sama menguasai pembelian atau penerimaan pasokan sebagaimana dimaksud dalam ayat (1) apabila 2 (dua) atau 3 (tiga) pelaku usaha atau kelompok pelaku usaha menguasai lebih dari 75\% (tujuh puluh lima persen) pangsa pasar satu jenis barang atau jasa tertentu.

Selanjutnya dalam pasal 14 yang berbunyi:

\section{Pasal 14}

Pelaku usaha dilarang membuat perjanjian dengan pelaku usaha lain yang bertujuan untuk menguasai produksi sejumlah produk yang termasuk dalam rangkaian produksi barang dan atau jasa tertentu yang mana setiap rangkaian produksi merupakan hasil pengolahan atau proses lanjutan, baik dalam satu rangkaian langsung maupun tidak langsung, yang dapat mengakibatkan terjadinya persaingan usaha tidak sehat dan atau merugikan masyarakat.

Serta penjelasan pasal 14 tersebut telah dijelaskan dalam penjelasan:

yang dimaksud dengan menguasai produksi sejumlah produk yang termasuk dalam rangkaian produksi atau yang lazim disebut integrasi vertikal adalah penguasaan serangkaian proses produksi atas barang tertentu mulai dari hulu sampai hilir atau proses yang berlanjut atas suatu layanan jasa tertentu oleh pelaku usaha tertentu. praktek integrasi vertikal meskipun dapat menghasilkan barang dan jasa dengan harga murah, tetapi dapat menimbulkan persaingan usaha tidak sehat yang merusak sendi-sendi perekonomian masyarakat. praktek seperti ini dilarang sepanjang menimbulkan persaingan usaha tidak sehat dan atau merugikan masyarakat.

Serta terdapat dalam pasal 17 tentang monopoli yang berbunyi:

Pasal 17

(1) Pelaku usaha dilarang melakukan penguasaan atas produksi dan atau pemasaran barang dan atau jasa yang dapat mengakibatkan terjadinya praktek monopoli dan atau persaingan usaha tidak sehat.

(2) Pelaku usaha patut diduga atau dianggap melakukan penguasaan atas produksi dan atau pemasaran barang dan atau jasa sebagaimana dimaksud dalam ayat (1) apabila:

a. barang dan atau jasa yang bersangkutan belum ada substitusinya; atau

b. mengakibatkan pelaku usaha lain tidak dapat masuk ke dalam persaingan usaha barang dan atau jasa yang sama; atau

c. satu pelaku usaha atau satu kelompok pelaku usaha menguasai lebih dari 50\% (lima puluh persen) pangsa pasar satu jenis barang atau jasa tertentu.

Dengan penjelasan beberapa pasal diatas sangat banyak unsur yang dapat menjerat pelaku monopoli dan persaingan usaha tidak sehat yang bahkan memanfaatkan kesempatan dalam keadaan pandemic covid 19 yang terjadi di Indonesia. Satu dan lain hal harus dipertimbangkan dalam pemberlakuan aturan aturan ini, disatu sisi pemerintah harus menemukan peraturan yang sesuai untuk bisa mengatasi lemahnya ekonomi dan kelangkaan alat kesehatan dalam mengahadapi pandemic tersebut. Tetapi dengan keringanan dan dorongan pemerintah untuk perusahaanperusahaan mengganti ranah produksinya maka bisa saja perusahaan-perusahaan besar sebelumnya tidak memproduksi alat alat kesehatan, dapat menguasai produksi dan wilayah pemasaran yang dapat menjatuhkan dan menekan perusahaan yang sebenarnya memiliki izin produksi resmi sebelum terjadinya covid 19 .

Tetapi walaupun dalam UU Nomor 5 tahun 1999 banyak yang membatasi tindakan monopoli, terdapat pengecualian yang diberikan dalam undang-undang ini agar dapat menghidari pasal pasal tersebut dengan adanya pasal 51 dalam undang undang ini yang berbunyi: 
Monopoli dan atau pemusatan kegiatan yang berkaitan dengan produksi dan atau pemasaran barang dan atau jasa yang menguasai hajat hidup orang banyak serta cabang-cabang produksi yang penting bagi negara diatur dengan undangundang dan diselenggarakan oleh Badan Usaha Milik Negara dan atau badan atau lembaga yang dibentuk atau ditunjuk oleh Pemerintah.

Dari pasal ini dapat dilihat bahwa pemerintah memasukan keadaan covid 19 sebagai tuntutan dalam keperluan yang menyangkut hajat orang banyak yang dapat menyampingkan terjadinya monopoli atau tindakan persaingan usaha tidak sehat selama tindakan atau perusahaan yang bertindak ditunjuk langsung atau diperintahkan oleh aturan yang lain yang diberikan pemerintah.

\section{KESIMPULAN}

Tahun 2020 menjadi tahun yang cukup berat untuk Dunia khususnya Indonesia, sebuah wabah virus yang bernama Covid Virus Disease (Covid19) yang merebak ke seluruh penjuru dunia membuat kegiatan masyarakat dunia terganggu hingga anjloknya pertumbuhan ekonomi, Virus corona atau Covid-19 pertama kali ditemukan di Wuhan, China pada akhir 2019 lalu. Penyebaran virus yang belum ditemukan penawarnya itu hingga kini tak terkendali. Sudah 200 lebih negara di dunia melaporkan adanya kasus terpapar virus corona. Indonesia adalah Negara hukum dimana segala sesuatu kegiatan diatas territorial Indonesia harus dilandaskan dan dijalankan berdasarkan aturan hukum yang berlaku, Dunia usaha merupakan suatu dunia yang boleh dikatakan tidak dapat berdiri sendiri. Pemerintah memberikan kelonggaran dan dorongan bagi para pelaku usaha agar dapat memproduksi alat kesehatan untuk membantu persediaan selama pandemic covid19, hal ini menjadi peluang untuk perusahaan besar untuk menguasai produksi dan wilayah pemasaran dan mengancam perusahaan yang sebelumnya telah memiliki izin produksi resmi sebelum pandemic covid19. Beberapa pasal dalam UU Nomor 5 tahun 1999 tentang larangan praktik monopoli dan persaingan usaha tidak sehat untuk mencega terjadinya praktik monopoli tersebut, tetapi dalam hal ini UU Nomor 5 tahun 1999 juga memberikan pengecualian dalam pasal 51 untuk dibenarkan terjadinya praktik monopoli selama ditetapkan lain atau ditujuk oleh undang-undang.

\section{SARAN}

Walaupun dalam hal ini diberikan pengecualian oleh Undang-Undang untuk melakukan praktik monopoli atau persaingan usaha, pemerintah melalui KPPU harus lebih ketat dalam mengawasi perusahaanperusahaan agar tidak menyalahgunakan kewenangan yang diberikan demi terciptanya keseimbangan dalam dunia usaha.

\section{DAFTAR PUSTAKA \\ BUKU}

Ahmad Yani dan Gunawan Widjaja, Seri Hukum Bisnis: Anti Monopoli, Cetakan Kedua, (Jakarta: Rajagrafindo Persada, 2000),

Mustafa Kamal Rokan, Hukum Persaingan Usaha Teori dan Praktiknya di Indonesia (Jakarta: Raja Grafindo Persada, 2012),

Susanti Adi Nugroho, Hukum Persaingan Usaha Di Indonesia Dalam Teori Praktik Serta Penerapan Hukumnya, Edisi Pertama, (Jakarta: Kencana, 2012),

Mohammad Taufik Makarao, dan Suharsil, Hukum Larangan Praktik Monopoli dan Persaingan Usaha Tidak Sehat (Bogor: Ghalia Indonesia, 2010),

\section{JURNAL}

Indonesia 2015a. Profil Kesehatan Indonesia Tahun 2014, Jakarta, Kementerian Kesehatan RI

WHO 2011. Development of Medical Device Policies, Jenewa, WHO Press

Nazmi, Implementasi Kebijakan
Pengembangan Industri Alat
Kesehatan Dalam Negeri, Jurnal
Kebijakan Kesehatan Indonesia :
JKKI, Vol. 07, No. 01 Maret 2018

Mashur Malaka, "Praktik Monopoli dan Persaingan Usaha," Jurnal Syariah dan Ekonomi Islam STAIN Kendari Vol. 7 No. 2 (Juli 2014),

\section{WEBSITE BERITA}


Jurnal Ilmu Sosial dan Pendidikan

http://ejournal.mandalanursa.org/index.php/JISIP/index

Terakreditasi Peringkat 5 (No. SK: 85/M/KPT/2020)
Vol. 4. No. 4 November 2020

p-ISSN: 2598-9944 e- ISSN: 2656-6753

https://news.detik.com/berita/d-

4956764/penyebab-asal-mula-dan-

pencegahan-virus-corona-di-

indonesia, Diakses tanggal $26 \mathrm{Mei}$

2020

https://kompas.id/,

https://www.bbc.com/indonesia/

https://www.bps.go.id/ 